\title{
Brown carbon in tar balls from smoldering biomass combustion
}

\author{
R. K. Chakrabarty ${ }^{1}$, H. Moosmüller ${ }^{1}$, L.-W. A. Chen $^{1}$, K. Lewis ${ }^{2}$, W. P. Arnott $^{2}$, C. Mazzoleni ${ }^{3,4}$, M. K. Dubey ${ }^{4}$, \\ C. E. Wold ${ }^{5}$, W. M. Hao ${ }^{5}$, and S. M. Kreidenweis ${ }^{6}$ \\ ${ }^{1}$ Division of Atmospheric Sciences, Desert Research Institute, Reno, NV, 89512, USA \\ ${ }^{2}$ Department of Physics, University of Nevada, Reno, NV, 89557, USA \\ ${ }^{3}$ Department of Physics, Michigan Technological University, MI, 49931, USA \\ ${ }^{4}$ Geochemistry and Climate Focus Team, Los Alamos National Laboratory, NM, 87547, USA \\ ${ }^{5}$ Fire Sciences Laboratory, USDA Forest Service, Missoula, MT, 59808, USA \\ ${ }^{6}$ Department of Atmospheric Sciences, Colorado State University, CO, 80523, USA
}

Received: 25 February 2010 - Published in Atmos. Chem. Phys. Discuss.: 8 March 2010

Revised: 12 June 2010 - Accepted: 2 July 2010 - Published: 13 July 2010

\begin{abstract}
We report the direct observation of laboratory production of spherical, carbonaceous particles - "tar balls" - from smoldering combustion of two commonly occurring dry mid-latitude fuels. Real-time measurements of spectrally varying absorption Ångström coefficients (AAC) indicate that a class of light absorbing organic carbon (OC) with wavelength dependent imaginary part of its refractive index - optically defined as "brown carbon" - is an important component of tar balls. The spectrum of the imaginary parts of their complex refractive indices can be described with a Lorentzian-like model with an effective resonance wavelength in the ultraviolet (UV) spectral region. Sensitivity calculations for aerosols containing traditional OC (no absorption at visible and UV wavelengths) and brown carbon suggest that accounting for near-UV absorption by brown carbon leads to an increase in aerosol radiative forcing efficiency and increased light absorption. Since particles from smoldering combustion account for nearly three-fourths of the total carbonaceous aerosol mass emitted globally, inclusion of the optical properties of tar balls into radiative forcing models has significance for the Earth's radiation budget, optical remote sensing, and understanding of anomalous UV absorption in the troposphere.
\end{abstract}

Correspondence to: R. K. Chakrabarty (rajan.chakrabarty@dri.edu)

\section{Introduction}

A recent report by the Intergovernmental Panel on Climate Change (IPCC) (Forster et al., 2007) highlights large uncertainty in current estimates of direct radiative forcing (RF) due to organic carbon (OC) aerosols from biomass and fossil fuel burning. Most RF and optical remote sensing retrieval models use traditional optical properties of OC particles (i.e., OC absorption can be neglected in the visible and near visible spectral region) (Forster et al., 2007; Chung and Seinfeld, 2002). Recently, a class of OC compounds with an imaginary part of its refractive index that increases towards shorter wavelengths - optically defined as brown carbon (Andreae and Gelencser, 2006; Moosmüller et al., 2009) - has been shown to absorb solar radiation in the blue and near ultraviolet (UV), thereby modifying RF (Forster et al., 2007). Global inventories of black (BC) and organic carbon (OC) emitted from combustion (Bond et al., 2004) show that approximately $88 \%$ of total carbonaceous aerosol mass is emitted from biomass combustion, with approximately $80 \%$ of this emitted from the smoldering combustion phase (Einfeld et al., 1991).

Duff combustion has been shown to be one of the largest contributors to smoldering smoke production (Hille and Stephens, 2005; Neary et al., 1999). Duffs are often the dominant fuel in low intensity wildland fires and prescribed burns, and may smolder for an extended time period (days to months) (Rein, 2009). Consumption of duff in wildland fires is a direct function of fuel moisture and duff with a moisture content below $14 \%$ is totally consumed during a forest fire (Hille and Stephens, 2005). While flaming combustion produces mostly fractal-like black carbon (BC) particles, there

Published by Copernicus Publications on behalf of the European Geosciences Union. 
is limited knowledge about the properties of particles from smoldering duff combustion.

In this article, we report the direct observation of nearspherical particles (identified as "tar balls" (Chakrabarty et al., 2006)) produced from the smoldering combustion of two commonly occurring dry duffs : (a) Ponderosa Pine Duff (PPDuff), the partly decayed litter in a ponderosa pine (Pinus ponderosa) forest including a portion of the uppermost soil layer collected from a rural location near Missoula, Montana, USA; and (b) Alaskan Duff (AKDuff), the uppermost layer of soil with live and dead feathermoss (Pleurozium schreberi) collected from a spruce-feathermoss forest near Tok, Alaska, USA. Tar balls are a recently named type of near-spherical, atmospheric aerosol particles consisting of amorphous carbonaceous material, and have been found to exist in abundance in polluted continental air masses (Pósfai et al., 2004; Hand et al., 2005; Alexander et al., 2008). Ponderosa pine is commonly found in mountainous terrain of southwestern Canada and the Cascades, Sierra Nevada, and Rocky Mountains of the United States; spruce-feathermoss forests dominate the southern boreal forest zone, which includes a large portion of Alaska. We discuss the unique optical properties of tar balls, and highlight the need to include them into RF and optical remote sensing models due to their impact on climate change and aerosol retrieval.

\section{Experiment and analysis}

Experiments were conducted during 2003-2006 in the combustion facility of the United States Department of Agriculture (USDA) Forest Service Fire Sciences Laboratory (FSL) as part of a comprehensive study to investigate the physical, optical, and chemical properties of smoke particles emitted from combustion of common mid-latitude wildland fuels (McMeeking et al., 2009). The unique combustion facility was designed to mimic "real-world" combustion scenarios with appropriate dilution of the combustion emissions and fuel arrangement to approximate combustion conditions found in prescribed forest burns. PPDuff and AKDuff constitute two of the nine major duff species found in boreal and Northern American forest regions of the Northern Hemisphere (Kasischke et al., 2005). Together, these nine types of duff species contribute between 46 and $72 \%$ of all wildland fire carbon emissions in a given year (Kasischke et al., 2005). Smoldering combustion of approximately $200 \mathrm{~g}$ of PPDuff and AKDuff on a flat fuel bed (Fig. 1) produced white smoke that filled a large $\left(\approx 3300 \mathrm{~m}^{3}\right)$ chamber from which aerosol was sampled through a $\mathrm{PM}_{2.5}$ inlet and distributed through a manifold (Fig. 1) to a suite of instruments, namely a particle sampling unit for scanning electron microscopy (SEM), a dual wavelength $(405 \mathrm{~nm}$ and $532 \mathrm{~nm}$ ) and a single wavelength $(780 \mathrm{~nm})$ integrated photoacousticnephelometer (IPNs) (Arnott et al., 1999; Abu-Rahmah et al., 2006; Lewis et al., 2008), and an electrical low pressure im-

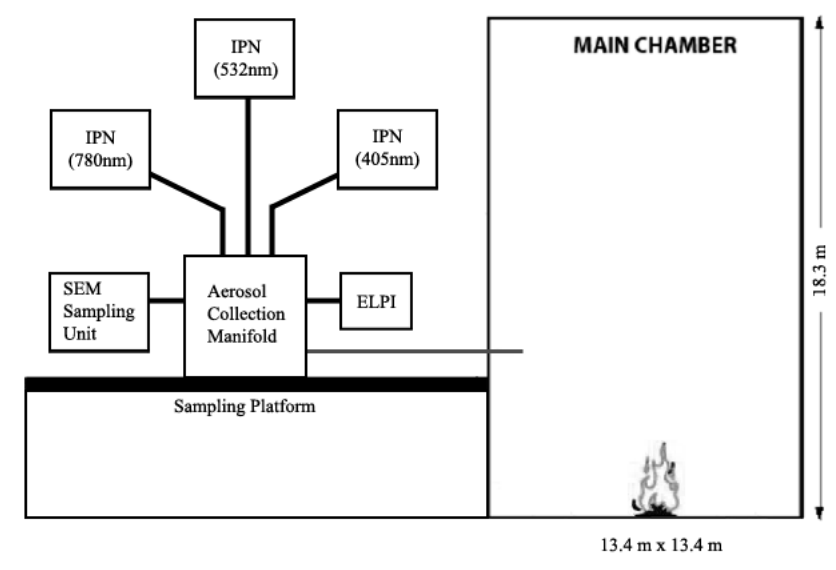

Fig. 1. Schematic diagram of the experimental setup used for smoldering combustion and characterization of emitted particles.

pactor (ELPI) (Marjamäki et al., 2000). Conductive tubing was used to transport the particles to the various instruments in order to minimize particle losses. PPDuff had a fuel moisture content (as fraction of dry mass) of $13.9 \%$ and burned with a modified combustion efficiency (MCE) - defined as the amount of carbon released as $\mathrm{CO}_{2}$ divided by the amount of carbon released as $\mathrm{CO}_{2}$ plus $\mathrm{CO}$ (Ward et al., 1996) - of 0.915, while AKDuff had a fuel moisture content (as a fraction of dry mass) of $9.2 \%$ and burned with a MCE of 0.902 . Smoke sampling for each smoldering burn lasted for approximately two hours, with only minimal flaming combustion during ignition.

Simultaneous measurements, with one-second time resolution, were performed to determine the scattering and absorption coefficients (IPN), and the particle size distribution and number concentration (ELPI). The IPN consists of a photoacoustic spectrometer and a reciprocal integrating nephelometer in one instrument using the same sample volume and laser beam. The photoacoustic spectrometer measures particle light absorption with a power-modulated laser beam inducing particle temperature changes and subsequent pressure changes of the surrounding air at the modulation frequency (Arnott et al., 1999). The reciprocal integrating nephelometer adds a cosine-weighted optical detector to the instrument that measures the integrated (over $\sim 4 \pi$ ) scattering from the sample volume yielding the scattering coefficient $B_{\text {sca }}$ (Abu-Rahmah et al., 2006). The two IPNs used in this study were operated with a modulation frequency of $1500 \mathrm{~Hz}$ to measure the scattering $\left(B_{\text {sca }}\right)$ and absorption $\left(B_{\text {abs }}\right)$ coefficients of the aerosols. For the SEM analysis, particles were impacted at a flow rate of $2 \mathrm{~L} / \mathrm{min}$ onto $10 \mu \mathrm{m}$ thick nuclepore clear polycarbonate 13-mm diameter filters (Whatman Inc, Chicago, IL) mounted on Costar Pop-Top Membrane holders. The filter exposure times for each of these burns were chosen, with the help of theoretical calculations involving factors such as flow rate and particle number concentration, 
to ensure moderate filter loading to help perform single particle analysis under a SEM. After sampling, the filter samples were kept in refrigerated storage and later prepared for SEM analysis by coating them with a 1-nm thick layer of platinum to prevent aerosol charging during SEM analysis. The coated filters were analyzed using a Hitachi Scanning Electron Microscope (Model S-4700).

The Electrical Low Pressure Impactor (ELPI) incorporates aerodynamic size classification with the electrical detection of particles in the range of several $\mathrm{nm}$ to $10 \mu \mathrm{m}$ (Marjamäki et al., 2000; Marjamaki and Keskinen, 2004; Virtanen et al., 2001). In ELPI, aerosol undergoes unipolar corona charging before passing through a low-pressure cascade impactor to separate particles of different aerodynamic diameters $\left(D_{a}\right)$. Electrometers record the current deposited on each impactor stage with a time resolution as low as $1 \mathrm{~s}$. Due to such a high time resolution, ELPI has been deployed to sample transientmode particle emission from automotive and biomass burning sources (Maricq et al., 2006; Latva-Somppi et al., 1998; Hays et al., 2004). The size resolution of ELPI is limited by 13 impactor stages (including a filter stage in this study). Primary particle collection efficiency of each stage is characterized by a size-cut $D_{a, 50}$ and a steepness coefficient $s$. Beside impaction, secondary collection mechanisms include diffusion, image charge and space charge effects, which are dependents of particle mobility diameter $\left(D_{p}\right)$ (Virtanen et al., 2001). An ELPI response function developed by Marjamaki et al. (2005) was followed in this study for retrieval of particle size-number concentration distribution. Kernel functions that transfer particle size-number concentration to measured current on stages by taking into account all primary and secondary collection mechanisms were constructed. $D_{a}$ is related to $D_{p}$ using:

$D_{a}^{2} C_{c}\left(D_{a}, \kappa_{i}\right) \rho_{0}=D_{p}^{2} C_{c}\left(D_{p}, \kappa_{i}\right) \rho_{p}$

where $C_{c}$ : Cunningham slip correction factor, which depends on particle size and mean free path

$\kappa_{i}$ : Particle mean free path at stage $i . i=1,2, \ldots, 13$

$\rho_{0}$ : Reference density $\left(1 \mathrm{~g} \mathrm{~cm}^{-3}\right)$

$\rho_{p}$ : Effective particle density

Equation (1) assumes nonporous spherical particles (Kelly and McMurry, 1992), which can apply to the smolderingcombustion particles observed in this study. An iterative, least-square-based inversion algorithm similar to (Dong et al., 2004) was used to retrieve particle size-number concentration from the kernel functions and ELPI current measurements. The size-number concentration was constrained to bimodal log-normal distributions, though it was found later that best fits usually consist of only single mode. To verify the robustness of the solution, multiple runs with random initial distribution were performed. They were compared with mobility number size distribution measurements from a Scanning Mobility Particle Sizer (SMPS) operated by a collaborating group during this experiment (McMeeking et al.,

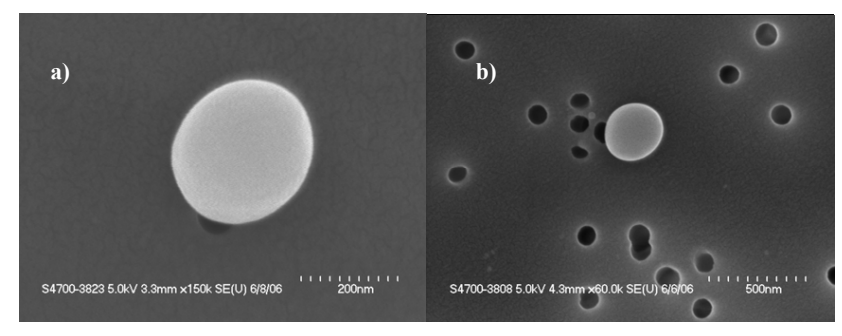

Fig. 2. Scanning electron microscopy (SEM) image of a typical tar ball emitted from smoldering biomass combustion of (a) Ponderosa Pine Duff, and (b) Alaskan Tundra Duff. Electron dispersive spectroscopy (EDX) of tar balls shows that these particles consist primarily of carbon and oxygen with an average molar ratio of about six.

2009). The ELPI modes generally agreed with those from the Scanning Mobility Particle Sizer (SMPS). However, due to a low time resolution of $\sim 10 \mathrm{~min}$ and size coverage of $\sim 0.04$ $0.6 \mu \mathrm{m}$, the SMPS data were not suitable for examining the optical closure of smoke particles. Further, the SMPS understated the total number concentrations due to the saturation limit of the condensation particle counter (CPC) detectors (TSI inc., 2003). Uncertainty of the ELPI retrieval results partly from the unknown particle density. From the literature, organic matter from biomass burning shows $\rho_{p}$ ranging from $0.79-1.53 \mathrm{~g} \mathrm{~cm}^{-3}$ (Reid et al., 2005). In this study the mean value of $1 \mathrm{~g} \mathrm{~cm}^{-3}$ was used (Radke et al., 1988; Radke et al., 1991), which gives equal aerodynamic and mobility diameter.

\section{Results and discussions}

SEM images (Fig. 2) reveal that typical smoke particles in this study were spherical and homogeneous tar balls (Pósfai et al., 2004; Hand et al., 2005; Alexander et al., 2008; Chakrabarty et al., 2006). A statistically relevant number of particles have been examined for morphology using SEM, and it was found that a high fraction (>95\%) of all particles from each of the three samples were tar balls. Electron dispersive spectroscopy (EDX) further confirmed the occurrence of tar balls by showing these particles to consist primarily of carbon and oxygen with an average molar ratio of about six, in agreement with previous observations (Pósfai et al., 2004; Hand et al., 2005; Alexander et al., 2008).

Figure 3 shows four-minute, time-averaged number size distributions of smoke particles determined by the ELPI. These size distributions are narrow with a single peak at $\sim 70 \mathrm{~nm}$ diameter, similar to the size distributions of tar balls obtained from the SAFARI and K-pustza samples (Pósfai et al., 2004). Previous chemical characterization of the particles, performed using scanning transmission $\mathrm{x}$-ray microscopy coupled with near-edge x-ray absorption fine structure spectroscopy (STXM/NEXAF), indicated a high 


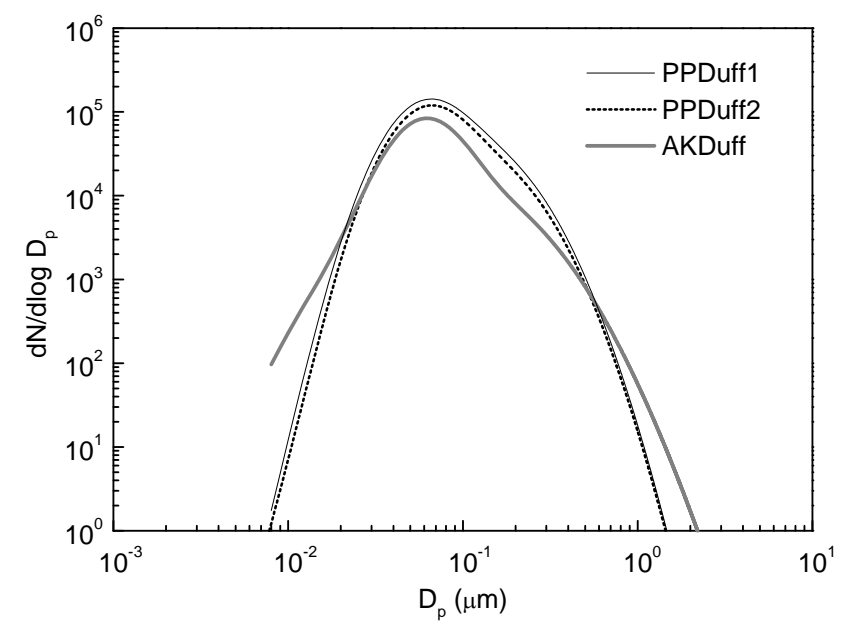

Fig. 3. Number size distribution of tar balls from the smoldering combustion of Ponderosa Pine Duff (PPDuff1 and PPDuff2) and Alaskan Tundra Duff (AKDuff) obtained from Electrical Low Pressure Impactor (ELPI) measurements. Each curve represents a four-minute average of second-by-second ELPI retrievals based on spherical, uniform particles and fitted with bi-modal, lognormal size-distribution functions.

proportion of oxygen-containing functional groups and very low $\mathrm{sp}^{2}$ hybridization (Hopkins et al., 2007). These findings clearly differentiate tar ball composition from that of BC particles, which are fractal-like aggregates of spherules that consist of concentrically wrapped graphitic layers with a low proportion of oxygen-containing functional groups and relatively high $\mathrm{sp}^{2}$ hybridization (Hopkins et al., 2007). The elemental carbon (EC) content of our aerosol samples was determined with a thermal-optical analysis method (Chow et al., 2004) and found to be below the detection limit.

Table 1 summarizes the experimentally determined optical properties of tar balls emitted from smoldering combustion of the two fuels described above. The complex refractive indices of the particles were retrieved from Mie "closure" calculations based on particle size, scattering, and absorption measurements. Use of Mie theory is justified by the near-spherical shape of the particles, and a Mie code similar to that of Guyon et al. (2003) and Hoffer et al. (2006) was used. Using the method of quadrature sum of the individual errors, the measurement errors in the real part of the index of refraction were calculated to be around $4.1 \%$ and that in the imaginary part were approximately $13.6 \%$.

The absorption Ångström coefficient (AAC) for a pair of wavelengths $\lambda_{1}$ and $\lambda_{2}$ is defined as

$\operatorname{AAC}\left(\lambda_{1}, \lambda_{2}\right)=-\ln \left[\beta_{\mathrm{abs}}\left(\lambda_{1}\right) / \beta_{\mathrm{abs}}\left(\lambda_{2}\right)\right] / \ln \left[\lambda_{1} / \lambda_{2}\right]$,

where $\beta_{\mathrm{abs}}$ is the absorption coefficient. The AAC characterizes the wavelength dependence of light absorption with $\mathrm{AAC}=1$ typical for BC (Reid et al., 2005; Moosmüller et al., 2009; Lewis et al., 2008). The spectrally varying AAC of the tar balls indicates that they can be categorized as brown carbon. Recent studies on humic-like substances (HULIS, related to brown carbon) and water-soluble OC (WSOC) (Hoffer et al., 2006; Kirchstetter et al., 2004; Moosmüller et al., 2009) have reported observation of AAC ranging between 6 and 7 for wavelengths between $300 \mathrm{~nm}$ and $532 \mathrm{~nm}$. The very high AAC of 6.4, observed between wavelengths $405 \mathrm{~nm}$ and $532 \mathrm{~nm}$ for tar balls from AKDuff, suggest the possibility of HULIS being a primary component. This inference is further strengthened by the similarities of the complex refractive index of tar balls and HULIS (Hoffer et al., 2006). The single scattering albedo (SSA) is the ratio of scattering to extinction coefficients, with the extinction coefficient being the sum of scattering and absorption coefficients (Bohren and Huffman, 1983). In the visible and near-visible range (i.e., $405 \mathrm{~nm}, 532 \mathrm{~nm}$, and $780 \mathrm{~nm}$ ), the SSA of tar balls emitted from smoldering combustion of PPDuff and AKDuff was fairly high (>0.93) (Lewis et al., 2008), increasing with wavelength - contrary to the decreasing SSA with increasing wavelength, typically observed for biomass burning aerosols (Chen et al., 2008). A very recent study also observed consistently higher SSA at $870 \mathrm{~nm}$ than at $405 \mathrm{~nm}$ for particles emitted from wildfires in Northern California (Gyawali et al., 2009). The SSA values for: PPDuff1 were $0.96(532 \mathrm{~nm})$ and 0.97 (780 nm); PPDuff2 were $0.93(405 \mathrm{~nm}), 0.97(532 \mathrm{~nm})$ and $0.98(780 \mathrm{~nm})$; and AKDuff were $0.95(405 \mathrm{~nm}), 0.98$ $(532 \mathrm{~nm})$ and $0.99(780 \mathrm{~nm})$. For ultra fine and fine (diameter $<1000 \mathrm{~nm}$ ) aerosol particles containing mixtures of $\mathrm{BC}$ and $\mathrm{OC}$, the wavelength dependence of their scattering and absorption coefficients are characterized by a scattering Ångström coefficient (SAC) of $3<\mathrm{SAC}<4$ (He et al., 2009) and AAC of $1<\mathrm{AAC}<4$ (Bergstrom et al., 2007). Therefore, the scattering efficiency generally drops faster with increasing wavelength than the absorption efficiency, explaining why aerosols containing mixtures of $\mathrm{BC}$ and $\mathrm{OC}$ have been typically observed to have decreasing SSA with increasing wavelength, corresponding to a positive SSA Ångström coefficient (defined similarly to AAC in Eq. 2). For the particles studied here however, their optical properties are dominated by brown carbon yielding an AAC as high as 6.4, significantly larger than their SAC. Therefore, for short wavelengths, the absorption coefficient drops faster with increasing wavelength than the scattering coefficient yielding negative SSA Ångström coefficients as shown in Table 1. For carbonaceous particles, negative SSA Ångström coefficients may become a useful criteria for the definition of brown carbon.

The derived refractive indices of the observed combustion particles are fuel and time dependent, and agree with recently reported results (Guyon et al., 2003; Hoffer et al., 2006; Hungershoefer et al., 2008). The imaginary part of refractive index corresponding to the fuel types in Table 1 can be fitted with a simple function of wavelength $\lambda$ as: 
Table 1. Summary of the experimentally determined optical properties of tar balls emitted from the combustion of two fuels: Ponderosa Pine Duff (PPDuff, at two sampling times) and Alaskan Duff (AKDuff).

\begin{tabular}{|c|c|c|c|c|c|c|c|c|c|c|}
\hline \multirow[b]{2}{*}{ Fuel Name } & \multicolumn{3}{|c|}{$\begin{array}{l}\text { Scattering and Absorption Coefficients } \mathrm{B}_{\mathrm{sca}} \\
\qquad \& \mathrm{~B}_{\mathrm{abs}}\left(\mathrm{Mm}^{-1}\right)\end{array}$} & \multicolumn{3}{|c|}{ Complex Refractive Index } & \multicolumn{2}{|c|}{$\begin{array}{c}\text { Absorption } \\
\text { Ångström Coefficient }\end{array}$} & \multicolumn{2}{|c|}{$\begin{array}{l}\text { SSA Ångström } \\
\text { Coefficient }\end{array}$} \\
\hline & $405 \mathrm{~nm}$ & $532 \mathrm{~nm}$ & $780 \mathrm{~nm}$ & $405 \mathrm{~nm}$ & $532 \mathrm{~nm}$ & $780 \mathrm{~nm}$ & $405-532 \mathrm{~nm}$ & $532-780 \mathrm{~nm}$ & $405-532 \mathrm{~nm}$ & $532-780 \mathrm{~nm}$ \\
\hline PPDuff $1^{\mathrm{a}}$ & N/A & $1543 \& 60.4$ & $731 \& 21$ & N/A & $1.72+0.008 \mathrm{i}$ & $1.71+0.006 \mathrm{i}$ & N/A & 2.8 & N/A & 0.027 \\
\hline PPDuff $2^{b}$ & $1807 \& 36$ & $1527 \& 42.8$ & $792 \& 18$ & $1.78+0.015 \mathrm{i}$ & $1.87+0.006 \mathrm{i}$ & $1.86+0.004 \mathrm{i}$ & 4.2 & 2.3 & -0.15 & -0.027 \\
\hline AKDuff ${ }^{b}$ & $1150 \& 56$ & $907 \& 9.7$ & $467 \& 3.9$ & $1.83+0.0076 \mathrm{i}$ & $1.75+0.0020 \mathrm{i}$ & $1.60+.0014 i$ & 6.4 & 2.4 & -0.15 & -0.008 \\
\hline
\end{tabular}

a Data set collected four minutes after ignition of fuel. During sampling, the IPN at $405 \mathrm{~nm}$ was not operating.

$\mathrm{b}$ Data set collected $30 \mathrm{~min}$ after ignition of the fuel.

$$
\begin{aligned}
& k(\lambda)=\frac{k_{\mathrm{BC}} V_{\mathrm{BC}}+k_{\mathrm{BrC}} V_{\mathrm{BrC}}}{V_{\mathrm{BC}}+V_{\mathrm{BrC}}}= \\
& k_{\mathrm{BC}} \frac{V_{\mathrm{BC}}}{V_{\mathrm{BC}}+V_{\mathrm{BrC}}}+\frac{a}{\left(\lambda^{2}-\lambda_{0}^{2}\right)^{2}} \frac{V_{\mathrm{BrC}}}{V_{\mathrm{BC}}+V_{\mathrm{BrC}}},
\end{aligned}
$$

where $\lambda_{0}$ is an effective resonance wavelength and $a$ is a constant (see Fig. 4a). The retrieved imaginary refractive index can be described as the sum of a wavelengthindependent component $k_{\mathrm{BC}}$ occurring in the very small $\mathrm{BC}$ volume fraction $\left(V_{\mathrm{BC}}\right)$ and a wavelength-dependent component $k_{\mathrm{BrC}}$ occurring in the dominant brown carbon volume fraction $\left(\mathrm{V}_{\mathrm{BrC}}\right)$. The wavelength-dependent component is modeled with a simple, Lorentzian-like $1 /\left(\lambda-\lambda_{0}\right)^{2}$ function (Demtröder, 2003). For wavelengths closer to the effective resonance wavelength, the line width would have to be accounted for in equation 3. In Fig. 4a, note that the assumption of identically wavelength dependent $k_{\mathrm{BrC}}$ for the two Ponderosa Pine Duff data sets still yields excellent fits (fit errors $\approx 1 \%$ ) of the data points. Calculating $k_{\mathrm{BrC}}$ by subtracting $k_{\mathrm{BC}}$ from our data (Fig. 4b) makes it obvious that the brown carbon component of the imaginary part of the refractive index is virtually identical for smoke particles from PPDuff1 and PPDuff2 (Fig. 4b). However, the $k_{\mathrm{BC}}$ component of PPDuff2 is less than $2 / 3$ of that of PPDuff1. This is probably due to the later sampling time for PPDuff2 when additional smoldering emissions and/or additional condensation of semi-volatile organic compounds added more brown carbon to the aerosol, while $\mathrm{BC}$ content stayed constant as minor flaming combustion during the ignition of the fire (the source of BC) had already terminated. The effective resonance wavelength of smoke particles from PPDuff was found to be further in the UV (i.e., $289 \mathrm{~nm}$ ) than that of AKDuff (i.e., $348 \mathrm{~nm}$ ).

The knowledge of $k_{\mathrm{BrC}}$ allows to estimate the radiative forcing efficiency (RFE; the radiative forcing per unit optical depth and bandwidth) at $405 \mathrm{~nm}, 532 \mathrm{~nm}$, and $780 \mathrm{~nm}$ by brown carbon emitted from PPDuff 2 and AKDuff combustion (Table 2). In order to assess the contribution of absorption by brown carbon, the estimated RFE for brown carbon is compared with that of traditional OC (i.e., complex refractive index $=1.55+0 \mathrm{i}$ ) (Horvath, 1993). Most calculations of RF for traditional OC containing aerosols have assumed
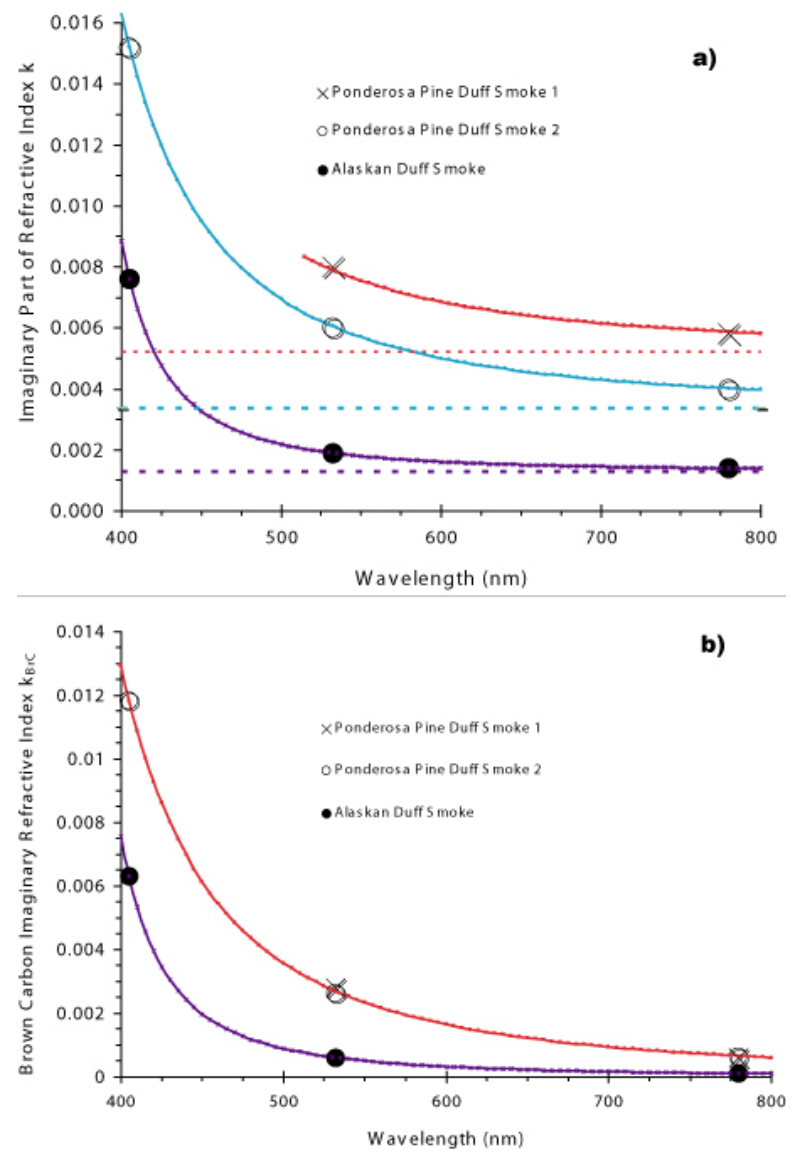

Fig. 4. (a) Data (individual points) and models (solid lines) of the imaginary part of the refractive index $k$ of the volume averaged contributions of black carbon (BC) and brown carbon $(\mathrm{BrC})$ as function of wavelength for Ponderosa Pine Smoke 1 and 2 and Alaskan Duff Smoke. The wavelength independent components $k_{\mathrm{BC}}$ of $k$ are shown as dotted lines for the three individual smoke samples. (b) Data (individual points) and models (solid lines) of the imaginary part of the refractive index $k$ as function of wavelength for the brown carbon component of Ponderosa Pine Smoke 1 and 2 and Alaskan Duff Smoke. The fact that the data points for Ponderosa Pine Smoke 1 and 2 are nearly identical indicates that differences in the imaginary parts of their refractive indices are predominantly due to different black carbon content. 
Table 2. Comparison of radiative forcing efficiency (i.e., radiative forcing per unit optical depth and bandwidth) at $405 \mathrm{~nm}$, $532 \mathrm{~nm}$, and $780 \mathrm{~nm}$ for brown carbon emitted from Ponderosa Pine Duff and Alaskan Duff combustion with that of traditional organic carbon.

\begin{tabular}{|c|c|c|c|c|c|c|c|c|c|}
\hline \multirow[t]{2}{*}{ Fuel Name } & \multicolumn{3}{|c|}{$\lambda=405 \mathrm{~nm}$} & \multicolumn{3}{|c|}{$\lambda=532 \mathrm{~nm}$} & \multicolumn{3}{|c|}{$\lambda=780 \mathrm{~nm}$} \\
\hline & Refractive Index & $\begin{array}{l}\text { RFE } \\
\left(\mathrm{W} / \mathrm{nm} \mathrm{m}^{2}\right)\end{array}$ & $\begin{array}{l}\text { Difference } \\
\left(\mathrm{W} / \mathrm{nm} \mathrm{m}^{2}\right)\end{array}$ & Refractive Index & $\mathrm{RFE}\left(\mathrm{W} / \mathrm{nm} \mathrm{m}^{2}\right)$ & $\begin{array}{l}\text { Difference } \\
\left(\mathrm{W} / \mathrm{nm} \mathrm{m}^{2}\right)\end{array}$ & Refractive Index & $\mathrm{RFE}\left(\mathrm{W} / \mathrm{nm} \mathrm{m}^{2}\right)$ & $\begin{array}{l}\text { Difference } \\
\left(\mathrm{W} / \mathrm{nm} \mathrm{m}^{2}\right)\end{array}$ \\
\hline PPDuff2 & $1.78+0.015 \mathrm{i}$ & -22.7 & & $1.87+0.003 i$ & -21.5 & & $1.86+0.0007 i$ & -16.6 & \\
\hline $\mathrm{OC}$ & $1.55+0.0 \mathrm{i}$ & -26.0 & +3.3 & $1.55+0.0 \mathrm{i}$ & -21.3 & -0.2 & $1.55+0.0 \mathrm{i}$ & -15.9 & -0.7 \\
\hline AKDuff & $1.83+0.006 \mathrm{i}$ & -22.0 & & $1.75+0.0006 \mathrm{i}$ & -19.9 & & $1.60+0.0001 i$ & -15.4 & -0.3 \\
\hline $\mathrm{OC}$ & $1.55+0.0 \mathrm{i}$ & -24.0 & +2 & $1.55+0.0 \mathrm{i}$ & -19.7 & -0.2 & $1.55+0.0 \mathrm{i}$ & -15.1 & \\
\hline
\end{tabular}

that $\mathrm{OC}$ does not absorb in the visible and near-visible part of the spectrum. The aerosol RFE was estimated in a similar fashion to Dinar et al. (2008) and Randles et al. (2004). The shortwave aerosol RFE at the top of the atmosphere caused by a uniform, optically thin aerosol layer in the lower troposphere was calculated using

$$
\frac{\Delta F}{\tau}=
$$

$S D\left(1-A_{\mathrm{cld}}\right) T_{\mathrm{atm}}^{2}\left(1-R_{\mathrm{sfc}}\right)^{2}\left[2 R_{\mathrm{sfc}} \frac{1-\mathrm{SSA}}{\left(1-R_{\mathrm{sfc}}\right)^{2}}-\beta(\mathrm{SSA})\right]$,

where $\Delta F$ is the change in net solar flux at the top of the atmosphere due to the presence of the aerosols, $\tau$ is the aerosol optical depth, $S$ is the solar constant, set to $1370 \mathrm{Wm}^{-2}, D$ is the fractional day length, set to $0.5, A_{\text {cld }}$ is the fractional cloud cover, set to $0.6, T_{\text {atm }}$ is the solar atmospheric transmittance, set to $0.76, R_{\mathrm{sfc}}$ is the surface albedo, set to 0.15 (appropriate for an urban area), and SSA is the aerosol single scattering albedo. The parameter $\beta$ is the fraction of scattered sunlight that is scattered into the upward hemisphere, which in turn is a function of hemispheric backscatter fraction, $b$, defined as the ratio of backscattering coefficient to total scattering coefficient. The parameter $b$ was determined from $g$, the asymmetric parameter, using

$b=\frac{1-g^{2}}{2 g}\left[\frac{1}{\sqrt{1+g^{2}}}-\frac{1}{1+g}\right]$.

From $b$, the parameter $\beta$ was calculated using the following functional relationship derived from the Henyey-Greenstein phase function (Henyey and Greenstein, 1941) as

$\beta=0.082+1.85 b-2.97 b^{2}$.

In all of the calculations, the relative humidity is assumed to be $0 \%$. The values of $k_{\mathrm{BrC}}$ directly affect the values of SSA and $\beta$ in Eq. (4).

In Table 2, positive values of RFE indicate heating and negative values cooling of the atmosphere by aerosols. As would be expected, the RFE of brown carbon is significantly less negative than the RFE of OC at $405 \mathrm{~nm}$, emphasizing the increasing importance of the absorbance by brown carbon near the UV compared to the visible.

\section{Conclusion}

Inclusion of the properties of tar balls into current RF aerosol models and optical remote sensing retrievals is an important step towards improving model accuracy. Given their abundance in the atmosphere (Alexander et al., 2008; Lukacs et al., 2007), these brown carbonaceous tar balls may account for a significant increase in the RFE (resulting in additional atmospheric absorption and warming) in the near-UV and UV region. Additionally, their presence may help explain anomalously large near-UV and UV solar light absorption observed in the troposphere (Jacobson, 1999).

Acknowledgements. It is a pleasure to thank J. L. Collett Jr., and W. M. Malm for organizing the combustion study at the FSL, R. Kreidberg for providing help in editing the manuscript, and the FSL staff and other participants for technical assistance and discussions. This work was supported in part by the Joint Fire Science Program of the US land management agencies and the US Department of Energy Atmospheric Science Program. Instrument development was supported by the National Science Foundation Major Research Instrumentation program.

Edited by: T. Kirchstetter

\section{References}

Abu-Rahmah, A., Arnott, W. P., and Moosmüller, H.: Integrating nephelometer with a low truncation angle and an extended calibration scheme, Meas. Sci. Technol., 17, 1723-1732, 2006.

Alexander, D. T. L., Crozier, P. A., and Anderson, J. R.: Brown carbon spheres in East Asian outflow and their optical properties, Science, 321, 833-836, 2008.

Andreae, M. O. and Gelencser, A.: Black carbon or brown carbon? The nature of light-absorbing carbonaceous aerosols, Atmos. Phys. Chem., 6, 3131-3148, doi:10.5194/acp-6-3131-2006, 2006.

Arnott, W. P., Moosmüller, H., Rogers, C. F., Jin, T., and Bruch, R.: Photoacoustic spectrometer for measuring light absorption by aerosol: Instrument description, Atmos. Environ., 33, 28452852, 1999.

Bergstrom, R. W., Pilewskie, P., Russell, P. B., Redemann, J., Bond, T. C., Quinn, P. K., and Sierau, B.: Spectral absorption properties of atmospheric aerosols, Atmos. Phys. Chem., 7, 5937-5943, doi:10.5194/acp-7-5937-2007, 2007. 
Bohren, C. F. and Huffman, D. R.: Absorption and scattering of light by small particles, John Wiley and Sons, New York, USA, 541 pp., 1983.

Bond, T. C., Streets, D. G., Yarber, K. F., Nelson, S. M., Woo, J.H., and Klimont, Z.: A technology-based global inventory of black and organic carbon emissions from combustion, J. Geophys. Res., 109, D14203, doi:10.1029/2003JD003697, 2004.

Chakrabarty, R. K., Moosmüller, H., Garro, M. A., Arnott, W. P., Walker, J. W., Susott, R. A., Babbitt, R. E., Wold, C. E., Lincoln, E. N., and Hao, W. M.: Emissions from the laboratory combustion of wildland fuels: Particle morphology and size, J. Geophys. Res., 111, D07204, doi:10.1029/2005JD006659, 2006.

Chen, W. T., Kahn, R. A., Nelson, D., Yau, K., and Seinfeld, J. H.: Sensitivity of multiangle imaging to the optical and microphysical properties of biomass burning aerosols, J. Geophys. Res., 113, doi:10.1029/2007JD009414, 2008.

Chow, J. C., Watson, J. G., Chen, L.-W. A., Arnott, W. P., Moosmüller, H., and Fung, K.: Equivalence of elemental carbon by thermal/optical reflectance and transmittance with different temperature protocols, Environ. Sci. Technol., 38, 4414-4422, 2004.

Chung, S. H., and Seinfeld, J. H.: Global distribution and climate forcing of carbonaceous aerosols, J. Geophys. Res., 107, doi:10.1029/2001JD001397, 2002.

Demtröder, W.: Laser spectroscopy: Basic concepts and instrumentation, 3 ed., Springer Verlag, Berlin, Heidelberg, New York, 380 pp., 2003.

Dinar, E., Riziq, A. A., Spindler, C., Erlick, C., Kiss, G., and Rudich, Y.: The complex refractive index of atmospheric and model humic-like substances (HULIS) retrieved by a cavity ring down aerosol spectrometer (CRD-AS), Faraday Discuss., 137, 279-295, 2008.

Dong, Y. J., Hays, M. D., Smith, N. D., and Kinsey, J. S.: Inverting cascade impactor data for size-resolved characterization of fine particulate source emissions, J. Aerosol Sci, 35, 1497-1512, 2004.

Einfeld, W., Ward, D. E., and Hardy, C.: Effects of fire behavior on prescribed fire smoke characteristics: A case study, in: Global biomass burning: Atmospheric, climatic, and biospheric implications, MIT Press, Cambridge, MA, USA, 412-419, 1991.

Forster, P., Ramaswamy, V., Artaxo, P., Berntsen, T., Betts, R., Fahey, D. W., Haywood, J., Lean, J., Lowe, D. C., Myhre, G., Nganga, J., Prinn, R., Raga, G., Schulz, M., and Van Dorland, R.: Changes in atmospheric constituents and in radiative forcing, in: Climate change 2007:The physical science basis. Contribution of working group $i$ to the fourth assessment report of the intergovernmental panel on climate change, edited by: Solomon, S., Qin, D., Manning, M., Chen, Z., Marquis, M., Averyt, K. B., Tignor, M., and Miller, H. L., Cambridge University Press, 2007.

Guyon, P., Boucher, O., Graham, B., Beck, J., Mayol-Bracero, O. L., Roberts, G. C., Maenhaut, W., Artaxo, P., and Andreae, M. O.: Refractive index of aerosol particles over the amazon tropical forest during LBA-EUSTACH 1999, J. Aerosol Sci., 34, 883907, 2003.

Gyawali, M., Arnott, W. P., Lewis, K., and Moosmüller, H.: In situ aerosol optics in Reno, NV, USA during and after the summer 2008 California wildfires and the influence of aerosol coatings, Atmos. Phys. Chem., 9, 14059-14079, 2009.

Hand, J. L., Malm, W. C., Day, D., Lee, T., Carrico, C., Carrillo, J.,
Collett Jr., J., Laskin, A., Wang, C., Cowin, J. P., and Iedema, M. J.: Optical, physical, and chemical properties of tar balls observed during the Yosemite aerosol characterization study, J. Geophys. Res., 110, doi:10.1029/2004JD005728, 2005.

Hays, M. D., Smith, N. D., and Dong, Y. J.: Nature of unresolved complex mixture in size-distributed emissions from residential wood combustion as measured by thermal desorptiongas chromatography-mass spectrometry, J. Geophys. Res., 109, $-, 2004$.

He, G. S., Qin, H. Y., and Zheng, Q.: Rayleigh, Mie, and Tyndall scatterings of polystyrene microspheres in water: Wavelength, size, and angle dependences, J. Appl. Phys., 105, 023110 , doi:10.1063/1061.3068473, 2009.

Henyey, L. C. and Greenstein, J. L.: Diffuse radiation in the galaxy, J. Astrophys., 93, 70-83, 1941.

Hille, M. G. and Stephens, S. L.: Mixed conifer forest duff consumption during prescribed fires: Tree crown impacts, For. Sci.e, 51, 417-424, 2005.

Hoffer, A., Gelencsér, A., Guyon, P., Kiss, G., Schmid, O., Frank, G. P., Artaxo, P., and Andreae, M. O.: Optical properties of humic-like substances (HULIS) in biomass-burning aerosols, Atmos. Phys. Chem., 6, 3563-3570, doi:10.5194/acp-6-3563-2006, 2006.

Hopkins, R. J., Lewis, K., Desyaterik, Y., Wang, Z., Tivanski, A. V., Arnott, W. P., Laskin, A., and Gilles, M. K.: Correlations between optical, chemical and physical properties of biomass burn aerosols, Geophys. Res. Lett., 34, L18806, doi:10.1029/2007GL030502, 2007.

Horvath, H.: Atmospheric light absorption - a review, Atmos. Environ., 27A, 293-317, 1993.

Hungershoefer, K., Zeromskiene, K., Iinuma, Y., Helas, G., Trentmann, J., Trautmann, T., Parmar, R. S., Wiedensohler, A., Andreae, M. O., and Schmid, O.: Modelling the optical properties of fresh biomass burning aerosol produced in a smoke chamber: Results from the EFEU campaign, Atmos. Chem. Phys., 8, 34273439, doi:10.5194/acp-8-3427-2008, 2008.

Jacobson, M. Z.: Isolating nitrated and aromatic aerosols and nitrated aromatic gases as sources of ultraviolet light absorption, J. Geophys. Res., 104, 3527-3542, 1999.

Kasischke, E. S., Hyer, E. J., Novelli, P. C., Bruhwiler, L. P., French, N. H. F., Sukhinin, A. I., Hewson, J. H., and Stocks, B. J.: Influences of boreal fire emissions on northern hemisphere atmospheric carbon and carbon monoxide, Global Biogeochem. Cy., 19, GB1012, doi:10.1029/2004GB002300, 2005.

Kelly, W. P. and McMurry, P. H.: Measurement of particle density by inertial classification of differential mobility analyzer generated monodisperse aerosols, Aerosol Sci. Technol., 17, 199-212, 1992.

Kirchstetter, T. W., Novakov, T., and Hobbs, P. V.: Evidence that the spectral dependence of light absorption by aerosols is affected by organic carbon, J. Geophys. Res., 109, D21208, doi:10.1029/2004JD004999, 2004.

Latva-Somppi, J., Moisio, M., Kauppinen, E. I., Valmari, T., Ahonen, P., Tapper, U., and Keskinen, J.: Ash formation during fluidized-bed incineration of paper mill waste sludge, J. Aerosol Sci., 29, 461-480, 1998.

Lewis, K., Arnott, W. P., Moosmuller, H., and Wold, C. E.: Strong spectral variation of biomass smoke light absorption and single scattering albedo observed with a novel dual-wavelength 
photoacoustic instrument, J. Geophys. Res., 113, D16203, doi:10.1029/2007JD009699, 2008.

Lukacs, H., Gelencser, A., Hammer, S., Puxbaum, H., Pio, C., Legrand, M., Kasper-Giebl, A., Handler, M., Limbeck, A., Simpson, D., and Preunkert, S.: Seasonal trends and possible sources of brown carbon based on 2-year aerosol measurements at six sites in Europe, J. Geophys. Res., 112, D23S18, doi:10.1029/2006JD008151, 2007.

Maricq, M., Xu, N., and Chase, R.: Measuring particulate mass emissions with the electrical low pressure impactor, Aerosol Sci. Technol., 40, 85-96, 2006.

Marjamaki, M. and Keskinen, J.: Estimation of the cutpoint of an impactor with porous substrates, J. Aerosol Sci., 35, 657-663, 2004.

Marjamäki, M., Keskinen, J., Chen, D.-R., and Pui, D. Y. H.: Performance evaluation of the electrical low-pressure impactor (ELPI), J. Aerosol Sci., 31, 249-261, 2000.

Marjamäki, M., Lemmetty, M., and Keskinen, J.: ELPI response and data reduction i: Response functions, Aerosol Sci. Technol., 39, 575-582, 2005.

McMeeking, G. R., Kreidenweis, S. M., Baker, S., Carrico, C. M., Chow, J. C., Collett, J. L., Hao, W. M., Holden, A. S., Kirchstetter, T. W., Malm, W. C., Moosmuller, H., Sullivan, A. P., and Wold, C. E.: Emissions of trace gases and aerosols during the open combustion of biomass in the laboratory, J. Geophys. Res., 114, D19210, doi:10.1029/2009JD011836, 2009.

Moosmüller, H., Chakrabarty, R. K., and Arnott, W. P.: Aerosol light absorption and its measurement: A review, J. Quant. Spectrosc. Rad. Trans., 110, 844-878, 2009.

Neary, D. G., Klopatek, C. C., DeBano, L. F., and Ffolliott, P. F.: Fire effects on belowground sustainability: A review and synthesis, For. Ecol. Manage., 122, 51-71, 1999.

Pósfai, M., Gelencsér, A., Simonics, R., Arató, K., Li, J., Hobbs, P. V., and Buseck, P. R.: Atmospheric tar balls: Particles from biomass and biofuel burning, J. Geophys. Res., 109, D06213, doi:10.1029/2003JD004169, 2004.
Radke, L. F., Hegg, D. A., Lyons, J. H., Brock, C. A., Hobbs, P. V., Weiss, R. E., and Rasmussen, R. A.: Airborne measurements on smokes from biomass burning, Aerosols and Climate, Hampton, VA, USA, 411-422, 1988.

Radke, L. F., Hegg, D. A., Hobbs, P. V., Nance, J. D., Lyons, J. H., Laursen, K. K., Weiss, R. E., Riggan, P. J., and Ward, D. E.: Particulate and trace gas emissions from large biomass fires in North America, in: Global biomass burning: Atmospheric, climatic, and biospheric implications, edited by: Levine, J. S., MIT Press, Cambridge, MA, USA, 209-224, 1991.

Randles, C. A., Russell, L. M., and Ramaswamy, V.: Hygroscopic and optical properties of organic sea salt aerosol and consequences for climate forcing, Geophys. Res. Lett., 31, L16108, doi:10.1029/2004GL020628, 2004.

Reid, J. S., Eck, T. F., Christopher, S. A., Koppmann, R., Dubovik, O., Eleuterio, D. P., Holben, B. N., Reid, E. A., and Zhang, J.: A review of biomass burning emissions, part III: Intensive optical properties of biomass burning particles, Atmos. Phys. Chem., 5, 827-849, doi:10.5194/acp-5-827-2005, 2005.

Rein, G.: Smouldering combustion phenomena in science and technology, Int. Rev. Chem. Eng., 1, 3-18, 2009.

TSI inc.: Manual for the series 3936 scanning mobility particle sizer (SMPS), TSI, Minnesota, USA, 818 pp., 2003.

Virtanen, A., Marjamaki, M., Ristimaki, J., and Keskinen, J.: Fine particle losses in electrical low-pressure impactor, J. Aerosol Sci, 32, 389-401, 2001.

Ward, D. E., Hao, W. M., Susott, R. A., Babbitt, R. E., Shea, R. W., Kauffman, J. B., and Justice, C. O.: Effect of fuel composition on combustion efficiency and emission factors for African Savanna ecosystems, J. Geophys. Res., 101, 23569-23576, 1996. 